Regards sur l'économie allemande

Bulletin économique du CIRAC

$88 \mid 2008$

Varia

\title{
Philosophie de la société
}

STEHR Nico, Die Moralisierung der Märkte. Eine Gesellschaftstheorie

\section{OpenEdition}

\section{Journals}

Édition électronique

URL : http://journals.openedition.org/rea/1793

DOI : $10.4000 /$ rea. 1793

ISBN : 978-2-8218-0872-0

ISSN : 1965-0787

\section{Éditeur}

CIRAC

\section{Édition imprimée}

Date de publication : 1 octobre 2008

ISSN : 1156-8992

Référence électronique

"Philosophie de la société », Regards sur l'économie allemande [En ligne], 88 | octobre 2008, mis en ligne le 09 décembre 2008, consulté le 22 septembre 2020. URL : http://journals.openedition.org/rea/ 1793 ; DOI : https://doi.org/10.4000/rea.1793

Ce document a été généré automatiquement le 22 septembre 2020

(C) CIRAC 


\title{
Philosophie de la société
}

\author{
STEHR Nico, Die Moralisierung der Märkte. Eine Gesellschaftstheorie
}

\section{RÉFÉRENCE}

STEHR Nico, Die Moralisierung der Märkte. Eine Gesellschaftstheorie, Suhrkamp Taschenbuch Wissenschaft, Suhrkamp Verlag, Francfort/Main, 2007, 380 p.

1 A l'heure où le « capitalisme » se trouve sur la sellette, voici un ouvrage qui permet de remettre les choses en place. L'auteur de cette philosophie de la société de la deuxième moitié du XXe siècle, professeur à l'Université de Friedrichshafen, nous rappelle en effet que, dans le monde industriel, les revenus réels moyens ont quadruplé, voire quintuplé en l'espace de 50 ans. Et que, les biens et services que nous consommons aujourd'hui n'ayant plus rien de comparable avec ceux d'autrefois, nos modes de consommation ont eux aussi profondément changé. Cela n'est pas nouveau. Mais ce dont nous sommes moins conscients, rappelle l'auteur, c'est que notre représentation du "marché » comme de ses modes de fonctionnement n'a, elle, guère varié. Elle plonge toujours ses racines dans un monde où richesse (prospérité) et accès à l'éducation (savoir) n'allaient pas de soi; un monde fait d'impuissance, de famine et d'analphabétisme. Comment s'explique cette rémanence d'un système de références totalement obsolète? Plongeons-nous, avec Nico Stehr, dans l'histoire de l'évolution de la dialectique entre morale et marché... (ib) 